\title{
Analysis of Bacteriological Quality of Domestic Water Sources in Kabale Municipality, Western Uganda
}

\author{
Alex Saturday ${ }^{*}$ (D) Johnson Runyonyozi $^{2}$ \\ ${ }^{1}$ Department of Environment and Natural Resources, Kabale University, Kabale, Uganda \\ ${ }^{2}$ Department of Community Health, Kabale University, Kabale, Uganda \\ Email: *salex@kab.ac.ug
}

How to cite this paper: Saturday, A. and Runyonyozi, J. (2019) Analysis of Bacteriological Quality of Domestic Water Sources in Kabale Municipality, Western Uganda. Journal of Water Resource and Protection, 11, 581-594.

https://doi.org/10.4236/jwarp.2019.115033

Received: January 29, 2019

Accepted: May 19, 2019

Published: May 22, 2019

Copyright $\odot 2019$ by author(s) and Scientific Research Publishing Inc. This work is licensed under the Creative Commons Attribution International License (CC BY 4.0).

http://creativecommons.org/licenses/by/4.0/

\begin{abstract}
In the present study, we assessed the bacteriological quality of water of drinking water sources in Kabale Municipality. A total of 28 water samples were collected from 14 water springs during the dry and wet season and analyzed for determination of Escherichia coli (E. coli), and Total Heterotrophic Bacteria (THB) using the membrane filtration method. Most water springs located in less than 20 meters away from residential areas were associated with bacterial contamination. The mean concentrations of E. coli, total coliforms, and THB were $24.07 \mathrm{CFU} / 100 \mathrm{ml}, 85.71 \mathrm{CFU} / 100 \mathrm{ml}$, and $197.07 \mathrm{CFU} / 100 \mathrm{ml}$, respectively in the wet season. While in the dry season, the mean concentrations were 2 $\mathrm{CFU} / 100 \mathrm{ml}, 10 \mathrm{CFU} / 100 \mathrm{ml}$, and $91 \mathrm{CFU} / 100 \mathrm{ml}$ for E. coli, total coliforms, and THB, respectively. There were significant differences between CFU of total coliforms, HTB, between wet and dry seasons $(p=0.026)$. Samples collected and analyzed during the wet season for total coliforms did not conform to WHO drinking water quality guideline value of no detection per $100 \mathrm{ml}$. The study concludes that the majority of spring water sources are located in less than 20 meters away from residential areas with significant paved areas, the presence of septic tanks and pit latrines. Wet season significantly affects the quality of domestic water sources than the dry season. The study recommends that spring water should be treated before drinking due to high bacteria concentrations which makes it unsafe for consumption.
\end{abstract}

\section{Keywords}

Water Quality, Drinking Water Sources, Total Coliform, E. coli

\section{Introduction}

Worldwide, water is an important component of living beings as it performs 
unique and indispensable activities [1]. However, due to many anthropogenic activities, freshwater resources are getting deteriorated at a faster rate. Increasing urban population growth, industrialization, and intensive farming have led to severe disturbance of drinking water across the world, resulting in limited access to clean and safe drinking water. Access to clean and safe drinking water is vital for a healthy life and human sustainability.

Globally, estimates indicate that more than 700 million people lack access to a safe drinking water source [2]. In Africa, Sub-Saharan Africa is most remarkably and disproportionately affected by lack of access to safe drinking water. Estimates show that 327 million people without access to safe drinking water live in Sub-Saharan Africa [2] [3]. Absurdly, people still drink unsafe water in spite of improved access to safe drinking water. Drinking water can be contaminated at the source, in the distribution system, during collection, transportation, and storage.

In Uganda, access to safe drinking water sources was approximately $76 \%$ in 2015. This is so because since the 1990s efforts were made to provide safe drinking water to the people through National Water and Sewerage Corporation (NWSC), and gravity flow scheme projects (Saturday et al. 2016). However, the burden of waterborne diseases remains a major challenge [4]. A study by [5] reported that $18.8 \%$ of children under the age of five in southwestern Uganda had diarrhea disease before 2012 demographic health survey. The report further indicated the child mortality rate at 90 deaths per 1000 live births. Most of these deaths result from diarrhea disease due to the consumption of unsafe drinking water.

In Kable Municipality, while more than $82 \%$ of inhabitants have access to treated pipe-borne water for drinking and domestic use, a reasonable proportion of people especially in slum areas rely on water springs as their main source of water for drinking and domestic use [5]. Unless water springs are protected for human consumption, its water may become hazardous human health and transmit some waterborne diseases. The main sources of contaminants in these water sources in urban areas are pit latrines, wastewater from residential areas, animal waste and effluent from sewage system [6]. Thus, people use water from doubtful sources, which put them at risk of waterborne illnesses.

Analysis of the bacteriological quality of drinking waters is important in determining the sanitary quality of domestic water sources. Indicator bacteria are used to evaluate the quality of drinking water because it would be next to impossible to accurately enumerate all pathogenic organisms that transmitted through contaminated water [7]. The use of indicator bacteria as the means of assessing the quality of drinking water has been of paramount importance in protecting the lives of water against waterborne diseases. The principle here is that the selected bacteria indicate either contamination or deteriorating water quality upon which protection of public health from waterborne diseases has been developed. The study therefore aimed at ascertaining the bacteriological quality of drinking water sources with particular emphasis on spring water sources of Kabale Municipality. 


\section{Materials and Methods}

\subsection{Location of the Study}

The study was conducted in Kabale Municipality (Figure 1) located in Kabale District, Southwestern Uganda, $406.78 \mathrm{~km}$ from Uganda's capital city, Kampala. Geographically, Kabale Municipality lies between longitudes $29^{\circ} 45^{\prime} 0$ "E and $30^{\circ} 15^{\prime} 0^{\prime \prime} \mathrm{E}$ and latitudes $0^{\circ} 1^{\prime} 0^{\prime \prime} \mathrm{S}$ and $1^{\circ} 29^{\prime} 0^{\prime \prime} \mathrm{S}$. It covers a total area of $33 \mathrm{~km}^{2}$ [8]. It borders with the sub-counties of Kitumba in the south, Bubare to the north and Kyanamira to the East [9]. The fairly densely populated Kabale municipality of about 49,667 people (UBOS, 2014) is divided into Kabale North, Kabale South, and Kabale Central divisions, and $82 \%$ of households are said to have access to improved drinking water sources [10]. The main sources of drinking water are treated pipe-borne water, and water springs. However, some municipal inhabitants practice rainwater harvesting practiced [10]. In spite of relatively high accessibility to improved water sources, a reasonable proportion of people rely on unimproved domestic water sources in outskirts of the Kabale Municipality. As a result, people greatly exert pressure on springs which are free of charge. Hence 14 water springs were randomly selected from the three divisions

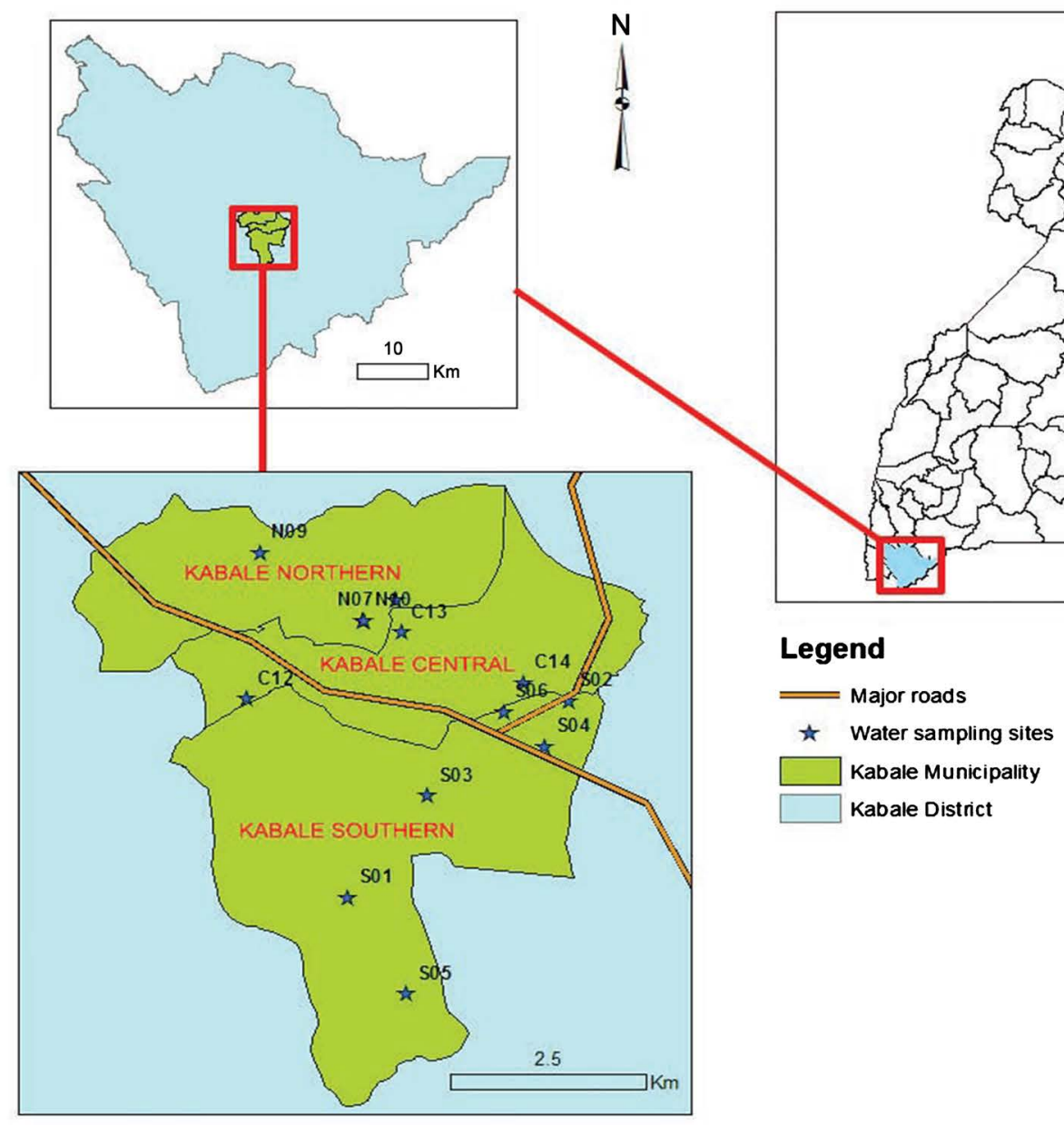

Figure 1. Map of Kabale municipality showing sampling locations. 
that make up Kabale Municipality viz; 5 springs from Kabale Northern Division, 5 from Kabale Southern Division, and 4 from Kabale Central Division.

\subsection{Sample Collection and Preparation}

A total of 28 spring water samples were collected from 14 water springs during dry and wet seasons. Samples were collected aseptically in sterilized $500 \mathrm{ml}$ sterile plastic bottles and then transported to National Waster Sewage Cooperation water quality laboratory for analysis. Before the transportation of water samples, the sampling bottle corks were shielded with aluminum foil in order to avoid any form of hand contamination and adhere to aseptic techniques. All samples were assigned identification numbers and the location of the source. Samples were analyzed as soon as possible after collection to avoid unpredictable changes in the bacterial population.

\subsection{Bacteriological Analysis}

Membrane filtration method which involves direct plating for detection and estimation of coliform was used in accordance with [11]. This method of analysis involved filtering $100 \mathrm{ml}$ of water sample through a $0.45 \mu \mathrm{m}$ millipore filter membrane that retained total coliform (TC) and Escherichia coli. For, heterotrophic bacteria count; $1 \mathrm{ml}$ of sample was filtered following procedures as for total coliforms. Funnel unit was placed carefully over the filter support assembly and was locked in place. Samples were poured into the funnel assembly then the filtered through the membrane-filter by applying a vacuum pump. Finally, the prepared culture dishes were incubated for 24 hours at $37^{\circ} \mathrm{C}, 24$ hours at $44^{\circ} \mathrm{C}$, and 48 hours at $37^{\circ} \mathrm{C}$ for determination of total coliforms E. coli and THB count, respectively. Upon completion of the incubation period, typical coliform colonies were seen on the membrane filter. All the colonies were counted with the aid of a magnifying lens [11].

\section{Results and Discussion}

\subsection{Characterization of Drinking Water Sources}

The potential threats and pathways of contamination of protected water springs were identified based on observed human activities in close proximity to water sources. This was accomplished during the field study visit to 14 water springs in Kabale Municipality. The study findings revealed that 8 (57.1\%), 7 (50\%), 4 (28.5\%), and 6 (42.8\%) of water springs sampled were situated in less than $20 \mathrm{~m}$ away from residential areas, toilet/ pit latrines, farming and eucalyptus tree plantations, respectively (Table 1).

Construction of toilets/pit latrines in close proximity to drinking water puts it at risk of feacal contamination. A study by [12] reported that River Cauvery in India was loaded with coliform bacteria attributable to raw sewage. In a related study, high concentration microbes in drinking water sources located in close proximity to pit latrines $(<20 \mathrm{~m})$ were reported [13]. Additionally, construction 
of residential houses in proximity or upstream to drinking water sources poses a threat to water contamination through leaching of contaminants. As shown in Plate 1, a water spring was found constructed in $<5 \mathrm{~m}$ adjacent to the residential area. It further observed that wastewater was flowing from the residential area into the water spring area. For instance, direct deposition of feces into the water body increases the survival rate of pathogens due to rapid sorption of contaminants onto bed sediments [14]. A study by [15] reported that animal manure and feces are key important sources of fecal contamination of drinking water sources in the agricultural watershed.

Farming was also another observed activity around water springs around that were studied (Table 1). Crops such as beans, potatoes, vegetables, and bananas were planted in close proximity to water sources. Interviews revealed the uncontrolled application of agricultural inputs such as fertilizers and pesticides. Animals were also observed in close proximity to water sources. These are potential threats to source water quality given the seemly high water table in some parts of Kabale Municipality and potential for surface runoffs and sediment transport.

Table 1. Observed activities/features in the vicinity to water sources (springs).

\begin{tabular}{|c|c|c|c|c|c|c|c|c|c|c|c|c|c|c|c|}
\hline \multirow{2}{*}{ Observed activities (in $<20 \mathrm{~m}$ ) } & \multicolumn{14}{|c|}{ Water sources } & \multirow{2}{*}{$\mathrm{T} / \mathrm{L}$} \\
\hline & S01 & S02 & S03 & S04 & S05 & N06 & N07 & N08 & N09 & N10 & $\mathrm{C} 11$ & $\mathrm{C} 12$ & $\mathrm{C} 13$ & $\mathrm{C} 14$ & \\
\hline Residential houses & & & & & & & & & & & & & & & 08 \\
\hline Waste disposal & & & & & & & & & & & & & & & 01 \\
\hline Toilet & & & & & & & & & & & & & & & 07 \\
\hline Farming & & & & & & & & & & & & & & & 04 \\
\hline Eucalyptus trees & & & & & & & & & & & & & & & 06 \\
\hline Total & 3 & 2 & 3 & 1 & 1 & 3 & 1 & - & 1 & 3 & & 3 & 3 & 2 & \\
\hline
\end{tabular}

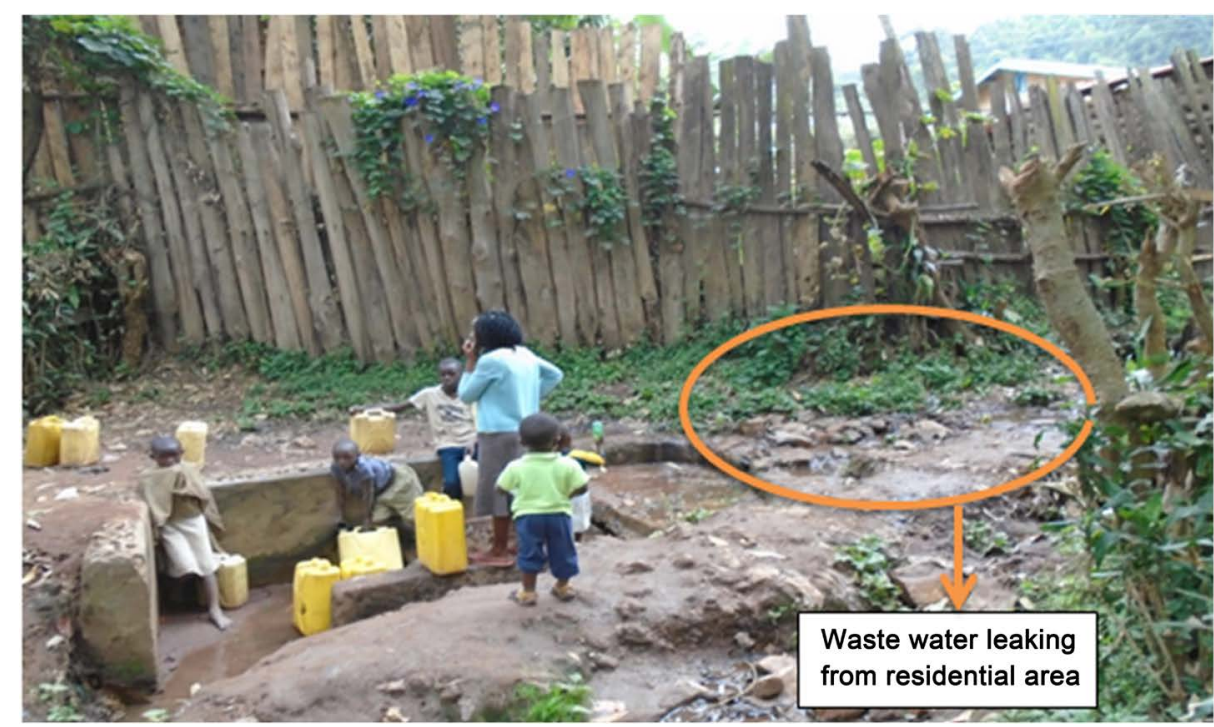

Plate 1. Water spring constructed in $<5 \mathrm{~m}$ away from a residential area and wastewater was seen flowing from the residential area. 
Establishing crop farms in close proximity to drinking water sources puts it at risk of chemical contamination especially when fertilizers, organic manure, and pesticides applied on crop farms end up in drinking water sources by runoff water after heavy rains. In a related study conducted by [16] reported high nitrate concentration in the majority of wells with typical values of $100-300 \mathrm{ppm}$ and exceeding $600 \mathrm{ppm}$ in some other areas of the Gaza Strip.

More to farming, eucalyptus trees were observed grown in close proximity to $42.8 \%$ of water springs. Eucalyptus is a unique tree species with the ability to efficiently adjust to surplus water situations when its water requirement rises to as high as 90 liters per plant per day. The Eucalyptus trees negatively affect the water springs by drawing much water to mean its daily water requirements (90 liters per day). A study by [17] in south Karnataka, India revealed a negative correlation between distance from the eucalyptus plantation and the depth of freshly dug bore wells. The study further revealed that bore well yields had reduced by 35 to $42 \%$ in the study area during the span of 3-5 years when they were located within a distance of $1 \mathrm{Km}$ from Eucalyptus plantations. A study by [18] reported that sap flow measurements showed transpiration rates of $2-3.7 \mathrm{~mm}$ $\mathrm{d}^{-1}$, lowering groundwater levels by more than $0.5 \mathrm{~m}$ with respect to the surrounding grassland. According to [19], Eucalyptus had deepened the water table by $0.762 \mathrm{~m}$ ( 0.833 yards) per year in the villages of Total and Kot. As a result, the average depth of the water table reached $20.116 \mathrm{~m}$ (22 yards) for Total village and $15.544 \mathrm{~m}$ (17 yards) for Kot village.

The tendency of drinking water contamination at the source depends on nature of the source, topography, and distance of septic tanks, distance from toilets, and other land use activities in close proximity to a water source. Whereas there are various agents of source water pollution, humans, animals, and precipitation (runoff) are principal agents of contaminant transport to a water source in the downstream areas. Constructed surfaces and bare soil increase the rate of runoff and provide channels between contaminants and source water [20]. Poorly positioned and improper functioning toilets and septic tanks have been linked to many outbreaks of waterborne diseases. Subsurface soil permeability or soil subject to inundation and steeply sloping sites enhance the likelihood of the presence of open pathways for contaminant transport.

\subsection{Bacteriological Quality of Domestic Water Samples}

Bacteriological analysis of water samples from 14 protected water springs in three divisions of Kabale Municipality showed that all samples were positive for total coliforms and heterotrophic bacteria counts. Unlike the thermotolerant $E$. coli which was at times not detected in the water sample especially in samples collected during the dry spell (Table 2).

\subsubsection{Total Coliforms (TC)}

Total coliforms counts ranged from 1 to $419 \mathrm{CFU} / 100 \mathrm{ml}$ and from 0 to 32 CFU/100 ml wet season and dry season, respectively (Table 2). The highest con- 
centration (419 CFU/100 ml) in the wet season occurred at Rushaki water spring (S02) followed by Kamatojo water spring (S01) with $211 \mathrm{CFU} / 100 \mathrm{ml}$. Kirigime water spring recorded the highest total coliform counts $(32 \mathrm{CFU} / 100 \mathrm{ml})$ in the dry season than any other source, followed by Kamatojo water spring (S01) with $20 \mathrm{CFU} / 100 \mathrm{ml}$ (Table 2). The mean values for total coliforms were 85.71 $\mathrm{CFU} / 100 \mathrm{ml}$ and $10.36 \mathrm{CFU} / 100 \mathrm{ml}$ in the wet season and dry season, respectively (Table 3 ). This pattern of total coliform counts indicates that water has come in contact with materials like human feces, soil, plants among others. However, their presence in drinking water indicates that disease-causing organisms could be in the water system [21].

In another related study conducted in South Africa, total bacterial count in sampled borehole water ranged from 1 to $44 \mathrm{CFU} / 100 \mathrm{ml}$ and from 1.0 to 579.4 CFU/100 ml during winter and spring, respectively [22]. With the exception of only one borehole out of eight, all borehole water samples were within the permissible standards of WHO drinking water standards [22].

Table 2. Results of biological analysis for spring waters from the study area.

\begin{tabular}{|c|c|c|c|c|c|c|}
\hline \multirow[t]{2}{*}{ Location } & \multicolumn{2}{|c|}{$\begin{array}{l}\text { Total Coliform } \\
\text { (CFU/100 ml) }\end{array}$} & \multicolumn{2}{|c|}{$\begin{array}{l}\text { Escherichia coli } \\
\text { (CFU/100 ml) }\end{array}$} & \multicolumn{2}{|c|}{$\begin{array}{c}\text { Total Heterotrophic } \\
\text { Bacteria }(\mathrm{CFU} / 100 \mathrm{ml})\end{array}$} \\
\hline & Wet season & Dry season & Wet season & Dry season & Wet season & Dry season \\
\hline 1. & 211 & 20 & 84 & 6 & 511 & 221 \\
\hline 2. & 419 & 0 & 138 & 0 & 225 & 7 \\
\hline 3. & 105 & 32 & 31 & 12 & 297 & 208 \\
\hline 4. & 10 & 15 & 0 & 1 & 132 & 88 \\
\hline 5. & 105 & 6 & 43 & 1 & 253 & 30 \\
\hline 6. & 1 & 24 & 0 & 2 & 80 & 225 \\
\hline 7. & 10 & 5 & 0 & 1 & 191 & 11 \\
\hline 8. & 23 & 0 & 5 & 0 & 30 & 10 \\
\hline 9. & 89 & 9 & 10 & 1 & 153 & 75 \\
\hline 10. & 56 & 17 & 17 & 5 & 211 & 168 \\
\hline 11. & 21 & 2 & 5 & 0 & 259 & 10 \\
\hline 12. & 17 & 0 & 4 & 0 & 84 & 10 \\
\hline 13. & 82 & 13 & 0 & 2 & 232 & 201 \\
\hline 14. & 51 & 2 & 0 & 0 & 101 & 4 \\
\hline Max. & 419 & 32 & 138 & 12 & 511 & 225 \\
\hline Min. & 1 & 0 & 0 & 0 & 30 & 4 \\
\hline Mean & 85.71 & 10.36 & 22.00 & 2.21 & 197.07 & 90.57 \\
\hline SD & 111.327 & 10.119 & 37.783 & 3.378 & 120.109 & 92.514 \\
\hline \multicolumn{7}{|l|}{ Standards } \\
\hline WHO (2006) & 0 & 0 & 0 & 0 & $<500$ & $<500$ \\
\hline UNBS (2008) & 0 & 0 & 0 & 0 & $<500$ & $<500$ \\
\hline
\end{tabular}


Table 3. Paired samples statistics between bacteria counts in the wet and dry season.

\begin{tabular}{cccccc}
\hline & & Mean & N & Std. Deviation & Std. Error Mean \\
\hline \multirow{2}{*}{ Pair 1 } & T.C wet & 85.71 & 14 & 111.33 & 29.75 \\
& T.C & 10.36 & 14 & 10.12 & 2.70 \\
Pair 2 & E.C & 24.07 & 14 & 40.43 & 10.81 \\
& E.Cet & 2.21 & 14 & 3.38 & 0.903 \\
Pair 3 & THB $_{\text {wet }}$ & 197.07 & 14 & 120.11 & 32.10 \\
& THB $_{\text {dry }}$ & 90.57 & 14 & 92.51 & 24.73 \\
\hline
\end{tabular}

\subsubsection{Thermotolerant E. coli}

With regards to thermotolerant E. coli, Samples were found to contain E. coli counts ranging from 0 to $138 \mathrm{CFU} / 100 \mathrm{ml}$ and from 0 to $12 \mathrm{CFU} / 100 \mathrm{ml}$ in the wet season and dry season, respectively and the maximum thermotolerant E. coli was highest at Rushaki water spring (S02) during the wet season (Table 2). The highest thermotolerant E. coli $(12 \mathrm{CFU} / 100 \mathrm{ml})$ were recorded at Kirigime water spring. Additionally, the study found out that $35.7 \%$ of water samples were free from thermotolerant $E$. coli in the dry season. The mean values for thermotolerant $E$. coli were $24.07 \mathrm{CFU} / 100 \mathrm{ml}$ and $2.21 \mathrm{CFU} / 100 \mathrm{ml}$ in the wet season and dry season, respectively (Table 2). The high level of thermotolerant $E$. coli recorded in this study may be attributed to the high degree of contamination of the water sources due to unhygienic practices in close proximity to water sources. The current study findings, however, disagree with [23] who reported that all water samples collected from unprotected water sources had fecal coliforms (FC), and $80 \%$ of samples had fecal coliforms ranging from 0.67 to $266.67 \mathrm{CFU} / 100$ ml. A related study by [24] reported high thermotolerant E. coli levels up to $62,000 \mathrm{CFU} / 100 \mathrm{ml}$ in drinking water sources in Central Gonja District.

According to [25], E. coli is a subgroup of the fecal coliform group. Most thermotolerant E. coli bacteria are harmless and exist in the intestines of warm-blooded animals and people. However, some strains can cause human illness. The presence of $E$. coli in a drinking water sample usually is indicative of recent fecal contamination [24]. E. coli O157: $\mathrm{H} 7$ strain is known to cause most outbreaks [21]. The water samples reported with $E$. coli does not necessarily mean that O157: H7 is present. It does indicate recent fecal contamination.

\subsubsection{Total Heterotrophic Bacteria (THB)}

The concentration of THB count varied from 30 to $511 \mathrm{CFU} / 100 \mathrm{ml}$ and from 4 to $225 \mathrm{CFU} / 100 \mathrm{ml}$ during the wet season and dry season, respectively (Table 2). The mean values for THB in wet and dry seasons were $197.07 \mathrm{CFU} / 100 \mathrm{ml}$ and $90.57 \mathrm{CFU} / 100 \mathrm{ml}$, respectively (Table 2). Various studies [26] [27] [28] have revealed major reasons for bacteriological contamination of water sources in urban centers as intermittent water supply which allows entry of any wastewater in the distribution system; layout of water pipes in close proximity to the sewer lines and overloading of sewage channels and sewers which in most cases remain 
blocked.

Paired samples T-test showed a significant difference between CFU of total coliforms in water samples collected during wet season $(M=85.71, S D=111.33)$ and dry season $(M=10.36, S D=10.12) ; t(13)=2.5, p=0.026$. Additionally, there was a significant difference between CFU of heterotrophic bacteria count in water samples collected during wet season $(M=197.07, S D=120.11)$ and dry season $(M=90.57, S D=92.51) ; t(13)=3.5, p=0.004$ (Table 3 and Table 4). There was no significant difference between CFU of $E$. coli in water samples collected during wet season $(M=24.08, S D=40.43)$ and dry season $(M=2.21, S D$ $=3.38) ; t(13)=2.0, p=0.062$ (Table 3 and Table 4$)$. These results indicate that during wet season, total coliforms and heterotrophic bacteria are abundant in water sources. For results showing significant no significant difference $(p>0.05)$ indicate that $E$. coli can be drinking water sources regardless of variations in season.

The study findings are in agreement with [29] who found out that concentrations of indicator bacteria were lower during the winter months and increased in April, which was when the first rains began. In addition, concentrations of total coliform and E. coli were significantly higher in the rainy seasons (ANOVA, $p<$ 0.01) [29]. However, the study findings do not concur with [30] who reported that during the rainy season, $E$. coli detection was significantly higher and most frequent compared to the dry season (all $p<0.05$ ). Fecal contamination in improved drinking water sources showed a statistically significant seasonal trend of greater contamination during the wet season $(p<0.001)$ [31].

\subsubsection{Risk Assessment of TC, Thermotolerant E. coli, and THB Contained in Spring Water Sources}

According to [32] and [33] standards, total coliforms and E. coli shouldn't be detected in $100 \mathrm{ml}$ of any drinking water sample and the concentration of heterotrophic bacteria should be $<500 \mathrm{CFU} / 100 \mathrm{ml}$. By this declaration, samples were drawn from drinking water sources with no detectable total coliforms and E. coli, and Heterotrophic Bacteria Count $<500 \mathrm{CFU} / 100 \mathrm{ml}$ were fit for drinking (Table 5). World Health Organization categories bacterial contamination into five different categories namely; $0 \mathrm{CFU} / 100 \mathrm{ml}$ (no risk/ in compliance), 1 to $10 \mathrm{CFU} / 100 \mathrm{ml}$ (low risk), 11 to 100 (medium risk), 101 to 1000 (high risk) and $<1000 \mathrm{CFU} / 100 \mathrm{ml}$ (Very high risk).

Table 4. Paired samples statistics between bacteria counts in wet and dry seasons (cont'd).

\begin{tabular}{|c|c|c|c|c|c|c|c|c|c|}
\hline & & \multicolumn{5}{|c|}{ Paired Differences } & \multirow{3}{*}{$t$} & \multirow{3}{*}{ df } & \multirow{3}{*}{$\begin{array}{c}\text { Sig. } \\
\text { (2-tailed) }\end{array}$} \\
\hline & & \multirow[b]{2}{*}{ Mean } & \multirow[b]{2}{*}{ Std. Deviation } & \multirow[b]{2}{*}{ Std. Error Mean } & \multicolumn{2}{|c|}{$\begin{array}{l}95 \% \text { Confidence Interval } \\
\text { of the Difference }\end{array}$} & & & \\
\hline & & & & & Lower & Upper & & & \\
\hline Pair 1 & T.C $C_{\text {wet }}-$ T. $C_{\text {dry }}$ & 75.36 & 112.49 & 30.06 & 10.41 & 140.31 & 2.51 & 13 & 0.026 \\
\hline Pair 2 & E. $C_{\text {wet }}-$ E. $C_{\text {dry }}$ & 21.86 & 40.06 & 10.72 & -1.28 & 44.98 & 2.04 & 13 & 0.062 \\
\hline Pair 3 & $\mathrm{THB}_{\text {wet }}-\mathrm{THB}_{\mathrm{dry}}$ & 106.50 & 115.03 & 30.74 & 40.08 & 172.91 & 3.46 & 13 & 0.004 \\
\hline
\end{tabular}


Table 5. Risk Assessment of TC, thermotolerant E. coli, and THB.

\begin{tabular}{|c|c|c|c|c|c|c|c|c|c|c|c|c|c|}
\hline \multirow{3}{*}{$\begin{array}{c}\text { Bacteria } \\
\text { contamination }\end{array}$} & \multirow[t]{3}{*}{ Remarks } & \multicolumn{2}{|c|}{$\begin{array}{l}\text { Total Coliform } \\
\text { (CFU/100 ml) }\end{array}$} & \multicolumn{2}{|c|}{$\begin{array}{l}\text { Total Coliform } \\
\text { (CFU/100 ml) }\end{array}$} & \multicolumn{2}{|c|}{$\begin{array}{c}\text { Thermotolerant } \\
\text { E. coli }(\mathrm{CFU} / 100 \\
\mathrm{ml})\end{array}$} & \multicolumn{2}{|c|}{$\begin{array}{l}\text { Thermotolerant } \\
\text { E. coli }(\mathrm{CFU} / 100 \\
\mathrm{ml})\end{array}$} & \multicolumn{2}{|c|}{$\begin{array}{c}\text { Total } \\
\text { Heterotrophic } \\
\text { Bacteria } \\
(\mathrm{CFU} / 100 \mathrm{ml})\end{array}$} & \multicolumn{2}{|c|}{$\begin{array}{c}\text { Total } \\
\text { Heterotrophic } \\
\text { Bacteria } \\
(\mathrm{CFU} / 100 \mathrm{ml})\end{array}$} \\
\hline & & Wet & Dry & Wet & Dry & Wet & Dry & Wet & Dry & Wet & Dry & Wet & Dry \\
\hline & & No. & No. & $\%$ & $\%$ & No. & No. & $\%$ & $\%$ & No. & No. & $\%$ & $\%$ \\
\hline$<1$ & No risk/Compliance & 0 & 4 & 0 & 28.6 & 5 & 5 & 35.7 & 35.7 & 0 & 0 & 0 & 0 \\
\hline $1-10$ & Low & 3 & 3 & 21.4 & 21.4 & 3 & 8 & 21.4 & 57.1 & 0 & 0 & 0 & 0 \\
\hline $11-100$ & Medium & 7 & 7 & 50.0 & 50.0 & 5 & 1 & 35.7 & 7.1 & 0 & 9 & 0 & 64.3 \\
\hline $101-1000$ & High risk & 4 & 4 & 28.6 & 28.6 & 1 & 0 & 7.1 & 0 & 14 & 5 & 100 & 35.7 \\
\hline$>1000$ & Very high risk & 0 & 0 & 0 & & 0 & 0 & 0 & 0 & 0 & & 0 & 0 \\
\hline
\end{tabular}

Majority of the water samples (50\%) tested for total coliforms fell within the medium risk category ( 11 to $100 \mathrm{CFU} / 100 \mathrm{ml}$ ) in the both dry and wet season. While $28.6 \%$ of water samples fell within the high-risk category in the wet season, none of the water samples fell within a high-risk category (101 to 1000 CFU/100 ml) in the dry season (Table 5). The study findings further indicate $57.1 \%$ of water samples tested for thermotolerant $E$. coli concentration fell within the low-risk category ( 1 to $10 \mathrm{CFU} / 100 \mathrm{ml}$ ). Additionally, $35.7 \%$ and $28.6 \%$ of samples had no thermotolerant $E$. coli detected during the dry season and wet season, respectively. The study findings closely with [30] who found out that $25 \%$ of source water samples had E. coli. The current study findings further revealed that only $7.1 \%$ of water samples fell within the high-risk category (101 $1000 \mathrm{CFU} / 100 \mathrm{ml}$ ) during the wet season (Table 5). For heterotrophic bacteria counts, (64.3\%) and (35.7\%) had colon forming units $<100 \mathrm{CFU} / 100 \mathrm{ml}$ and 100 1000 per $100 \mathrm{ml}$, respectively during the wet season. All water samples collected during dry season had THB counts ranging from 100 - $1000 \mathrm{CFU} / 100 \mathrm{ml}$ (Table 5).

A study by [34] found out that $80 \%$ of filtered water samples had no E. coli per $100 \mathrm{ml}$ and $17 \%$ were within a low-risk category ( 1 to $10 \mathrm{CFU} / 100 \mathrm{ml}$ ) in addition, [35] found out that all test water samples had bacteria counts $<10 \mathrm{CFU} / 100$ $\mathrm{ml}$ (low-risk category). In addition, [36] revealed that a total of $66 \%$ of all outfall samples had fecal indicator levels greater than 10,000 CFU/100 ml (high-risk level category).

\section{Conclusions}

Major of water sources are constructed with less in less than 20 meters away from residential areas. The mean concentrations of $E$. coli, total coliforms, and THB were $24.07 \mathrm{CFU} / 100 \mathrm{ml}, 85.71 \mathrm{CFU} / 100 \mathrm{ml}$, and $197.07 \mathrm{CFU} / 100 \mathrm{ml}$, respectively in the wet season. There were significant differences between CFU of total coliforms, HTB, between wet and dry seasons $(p=0.026)$. The study concludes that:

1) Drinking water collected and analyzed during the wet season for total coli- 
forms did not conform to WHO drinking water quality guideline value of no detection per $100 \mathrm{ml}$.

2) The quality of water from selected drinking water sources was compromised by anthropogenic activities such as farming latrines, landfills, and animal and municipal wastes, constructed in $<20$ meters away from these water sources.

3) Majority spring water sources (57.1\%) are located in less than 20 meters away from residential areas with significant paved areas, the presence of septic tanks and pit latrines.

4) Seasonal variations influence the concentration of bacteria in drinking water sources. For instance significant differences $(p=0.026)$ between CFU of total coliforms and heterotrophic bacteria count in water samples collected during wet seasons were noted.

5) Majority drinking water sources analyzed during wet season were in excess of WHO recommended guidelines for drinking water (WHO, 2006). This implies that water from these sources is not suitable for drinking without treatment.

\section{Recommendations}

Based on the study findings, the following are the recommendations to the policymakers, NGOs, and households in Kabale Municipality.

1) Spring water should be treated before drinking due to high bacteria concentrations which makes it unsafe for consumption. The responsibility to improve household drinking water must generally fall on individual households.

2) The government and NGOs should take an active role to ensure that residential areas are constructed at a distance of 20 meters away from spring water sources to prevent possible water contamination.

3) Nowadays, there are available cheap water testing methods to evaluate the bacteriological quality of water. The local people should always be involved in testing for bacteriological quality of water before use.

\section{Acknowledgements}

The Authors would wish to acknowledge the support offered to them by the Directorate of Research and Publication of Kabale University during the research and preparation of this paper.

\section{Conflicts of Interest}

The authors declare no conflict of interest.

\section{Data Availability Statement}

Data used to support the findings of this study are can be availed to you upon request.

\section{References}

[1] Srinivas, M. and Aruna, M. (2018) Physico-Chemical Analysis of a Lake, Erra Che- 
ruvu in Siddipet District of Angana State, India.

[2] WHO and UNICEF (2014) Progress on Drinking Water and Sanitation: 2014 Update.

[3] WHO and UNICEF (2010) Progress on Sanitation and Drinking-Water, 2010 Update.

[4] WHO and UNICEF (2015) WHO/UNICEF Joint Monitoring Programme for Water Supply and Sanitation. Estimates on the Use of Water Sources and Sanitation Facilities, 2015 Update.

[5] Saturday (2016) Household Water Treatment Technologies for Microbial Removal in Kabale District, Southwestern Uganda. https://doi.org/10.15436/2378-6841.16.804

[6] Lukubye, B. and Andama, M. (2017) Physico-Chemical Quality of Selected Drinking Water Sources in Mbarara Municipality, Uganda. Journal of Water Resource and Protection, 9, 707-722. https://doi.org/10.4236/jwarp.2017.97047

[7] Desalegn, A., Sissay, M. and Tesfaye, G. (2013) Microbiological Quality of Drinking Water Sources and Water Handling Practices among Rural Communities of Dire Dawa Administrative Council. International Journal of Current Research and Academic Review, 1, 29. https://doi.org/10.4314/star.v1i4.98818

[8] KMC (2009) Higher Local Government Statistical Abstract.

[9] KDLG (2012) Kabale District Local Government Statistical Abstract.

[10] DWD (2010) National Water Sewerage Corporation Supply and Distribution Report.

[11] APHA (1981) Standard Methods for the Examination of Water and Wastewater. 15th Edition, American Public Health Association, Washington DC.

[12] Sivaraja, R. and Nagarajan, K. (2014) Levels of Indicator Microorganisms (Total and Fecal Coliforms) in Surface Waters of Rivers Cauvery and Bhavani for Circuitously Predicting the Pollution Load and Pathogenic Risks. International Journal of PharmTech Research, 6, 455-461.

[13] Naser, A.M., Doza, S., Rahman, M., Ahmed, K.M., Gazi, M.S., Alam, G.R., Karim, M.R., Khan, G.K., Uddin, M.N. and Mahmud, M.I. (2019) Sand Barriers around Latrine Pits Reduce Fecal Bacterial Leaching into Shallow Groundwater: A Randomized Controlled Trial in Coastal Bangladesh. Environmental Science \& Technology, 53, 2105-2113. https://doi.org/10.1021/acs.est.8b04950

[14] Goss, M. and Richards, C. (2008) Development of a Risk-Based Index for Source Water Protection Planning, Which Supports the Reduction of Pathogens from Agricultural Activity Entering Water Resources. Journal of Environmental Management, 87, 623-632. https://doi.org/10.1016/j.jenvman.2006.12.048

[15] Liu, W.W., Jeppesen, E., Ma, J., Yang, M. and Trolle, D. (2019) Modeling the Fate and Transport of Cryptosporidium, a Zoonotic and Waterborne Pathogen, in the Daning River Watershed of the Three Gorges Reservoir Region, China. Journal of Environmental Management, 232, 462-474. https://doi.org/10.1016/j.jenvman.2018.10.064

[16] Abunada, Z. and Nassar, A. (2015) Impacts of Wastewater Irrigation on Soil and a Alfalfa Crop: Case Study from G Aza Strip. Environmental Progress \& Sustainable Energy, 34, 648-654. https://doi.org/10.1002/ep.12034

[17] Joshi, M. and Palanisami, K. (2011) Impact of Eucalyptus Plantations on Ground Water Availability in South Karnataka. ICID 21 st International Congress on Irrigation and Drainage, Tehran, 15-23 October 2011, 255-262. 
[18] Engel, V., Jobbágy, E.G., Stieglitz, M., Williams, M. and Jackson, R.B. (2005) Hydrological Consequences of Eucalyptus Afforestation in the Argentine Pampas. Water Resources Research, 41, W10409. https://doi.org/10.1029/2004WR003761

[19] Bilal, H., Nisa, S. and Ali, S.S. (2014) Effects of Exotic Eucalyptus Plantation on the Ground and Surface Water of District Malakand, Pakistan. International Journal of Innovation and Scientific Research, 8, 299-304.

[20] Davies, C.M., Ferguson, C.M., Kaucner, C., Krogh, M., Altavilla, N., Deere, D.A. and Ashbolt, N.J. (2004) Dispersion and Transport of Cryptosporidium Oocysts from Fecal Pats under Simulated Rainfall Events. Applied and Environmental Microbiology, 70, 1151-1159. https://doi.org/10.1128/AEM.70.2.1151-1159.2004

[21] WHO (2011) Guidelines for Drinking-Water Quality. WHO Chronicle, 38, 104-108.

[22] Palamuleni, L. and Akoth, M. (2015) Physico-Chemical and Microbial Analysis of Selected Borehole Water in Mahikeng, South Africa. International Journal of Environmental Research and Public Health, 12, 8619-8630. https://doi.org/10.3390/ijerph120808619

[23] Yasin, M., Ketema, T. and Bacha, K. (2015) Physico-Chemical and Bacteriological Quality of Drinking Water of Different Sources, Jimma Zone, Southwest Ethiopia. BMC Research Notes, 8, 541. https://doi.org/10.1186/s13104-015-1376-5

[24] Farenhorst, A., Li, R., Jahan, M., Tun, H.M., Mi, R., Amarakoon, I., Kumar, A. and Khafipour, E. (2017) Bacteria in Drinking Water Sources of a First Nation Reserve in Canada. Science of the Total Environment, 575, 813-819. https://doi.org/10.1016/j.scitotenv.2016.09.138

[25] WHO (2004) Guidelines for Drinking-Water Quality: Recommendations. World Health Organization, Geneva.

[26] Azizullah, A., Khattak, M.N.K., Richter, P. and Häder, D.-P. (2011) Water Pollution in Pakistan and Its Impact on Public Health-A Review. Environment International, 37, 479-497. https://doi.org/10.1016/j.envint.2010.10.007

[27] Haydar, S., Arshad, M. and Aziz, J.A. (2016) Evaluation of Drinking Water Quality in Urban Areas of Pakistan: A Case Study of Southern Lahore. Pakistan Journal of Engineering and Applied Sciences, 5, 16-23.

[28] Jain, C.K., Bandyopadhyay, A. and Bhadra, A. (2010) Assessment of Ground Water Quality for Drinking Purpose, District Nainital, Uttarakhand, India. Environmental Monitoring and Assessment, 166, 663-676. https://doi.org/10.1007/s10661-009-1031-5

[29] Kumpel, E. and Nelson, K.L. (2013) Comparing Microbial Water Quality in an Intermittent and Continuous Piped Water Supply. Water Research, 47, 5176-5188. https://doi.org/10.1016/j.watres.2013.05.058

[30] Ercumen, A., Pickering, A.J., Kwong, L.H., Arnold, B.F., Parvez, S.M., Alam, M., Sen, D., Islam, S., Kullmann, C. and Chase, C. (2017) Animal Feces Contribute to Domestic Fecal Contamination: Evidence from E. coli Measured in Water, Hands, Food, Flies, and Soil in Bangladesh. Environmental science \& technology, 51, 8725-8734. https://doi.org/10.1021/acs.est.7b01710

[31] Kostyla, C., Bain, R., Cronk, R. and Bartram, J. (2015) Seasonal Variation of Fecal Contamination in Drinking Water Sources in Developing Countries: A Systematic Review. Science of the Total Environment, 514, 333-343. https://doi.org/10.1016/j.scitotenv.2015.01.018

[32] WHO (2006) Water Supply, Sanitation and Hygiene Development. World Health Organization, Geneva. 
[33] UNBS (2008) Uganda Standard: Drinking (Potable) Water-Specification.

[34] Duke, W.F., Nordin, R.N., Baker, D. and Mazumder, A. (2006) The Use and Performance of BioSand Filters in the Artibonite Valley of Haiti: A Field Study of 107 Households. Rural Remote Health, 6, 570.

[35] Stevenson, M.M. (2008) Monitoring Effective Use of Household Water Treatment and Safe Storage Technologies in Ethiopia and Ghana. Massachusetts Institute of Technology, Cambridge.

[36] Sauer, E.P., VandeWalle, J.L., Bootsma, M.J. and McLellan, S.L. (2011) Detection of the Human Specific Bacteroides Genetic Marker Provides Evidence of Widespread Sewage Contamination of Stormwater in the Urban Environment. Water Research, 45, 4081-4091. https://doi.org/10.1016/j.watres.2011.04.049 